\title{
Conceptual Problems of the Right to Breathe Clean Air
}

\author{
Sava Jankovic ${ }^{1 *}$ \\ ${ }^{1}$ Department of Research and Science, Institute of Science and Culture, Oslo, Norway. \\ Corresponding author: Sava Jankovic, Email: s.jankovic@iosac.no
}

(Received 29 January 2020; revised 07 September 2020; accepted 16 September 2020)

\begin{abstract}
This Article undertakes the conceptual analysis of the right to breathe clean air, concentrating predominantly on the perplexities of this highly important environmental right. In its first part, this Article brings forward a few aspects illustrating general ambiguity and imprecision of the right. As will be shown, it is quite troublesome to firmly indicate which foundations (legal v. moral) or character (individual v. collective) the right to breathe clean air has, as well as to which category (generations of human rights) it belongs to. Similarly, its temporal determination (present-day v. future) is uncertain, and it is easy to confuse or conflate the substantive right with procedural rights. In the second part, this Article identifies and describes more serious and specific difficulties surrounding the right, which negatively influence conceiving the right to breathe clean air as a legal right. In the beginning, the reference is made to its nonautonomous character. Subsequently, this Article explores the issues of the content of the right, outlining problems with the meaning, the indeterminacy of the subjects of the said right, and its absence at the international level. Finally, this Article highlights hurdles concerning the enforceability of the right. This Article concludes that, at present, it is troublesome to conceptualize the right to breathe clean air as hard law, however, the situation may change in the future.
\end{abstract}

Keywords: Air pollution; right to clean air; human rights; environmental law; three generations of human rights; moral and legal rights; substantive and procedural rights

\section{A. Introduction}

In September 2018, the EU Court of Auditors published a report which stated that air pollution is the biggest environmental risk to public health in the European Union. According to the report, more than 1,000 premature deaths are triggered by air pollution, both ambient and household, every day across the EU. ${ }^{1}$

In view of the detrimental effects of air pollution on human health and the environment as a whole, the articulation of the right to breathe clean air can be construed as an imperative, which can warrant, one can rightly say, a basic entitlement of a community. Undoubtedly, more emphasis should be placed upon the right to clean air both in the academic discourse and within the

\footnotetext{
${ }^{*}$ Sava Jankovic is also the director for research and science at the Institute of Science and Culture in Norway.

${ }^{1}$ See Special Rep. of the Eur. Ct. of Auditors, Air Pollution: Our Health Still Insufficiently Protected, at 8 (2018), https://www. eca.europa.eu/Lists/ECADocuments/SR18_23/SR_AIR_QUALITY_EN.pdf; see also some concerning statistics from the World Health Organization (WHO) stating that 9 out of 10 people worldwide breathe polluted air, resulting in around 7 million premature deaths every year-4.2 million of these deaths are attributed to ambient pollution and 3.8 to household pollution. Air POllution, WORLD Health ORG. (2021), https://www.who.int/airpollution/en/.
} 
political sphere. As noted by an expert in the field, "[i]t is insufficient to treat clean air as a policy objective. It must be regarded as a fundamental human right."

The separate articulation of the right to breathe clean air in domestic legislation and international law will strengthen the environmental rule of law by filling the gaps in existing law, encouraging stronger environmental statutes, providing procedural protections, and heightening the significance of environmental law in society. Accordingly, the presence of the right will provide agencies with the authority to act, oblige companies to act sustainably, and above all, create direct corresponding obligations on states, providing people with the ability to seek justice.

In fact, states already must monitor air quality and health effects, assess the sources of air pollution, conduct public reporting on air quality, create air quality action plans, secure access to justice in environmental matters, as well as establish and maintain substantive environmental standards that are non-discriminatory and non-retrogressive. But these are obligations stemming from procedural rights rather than the substantive right to breathe clean air. Such procedural rights are not tantamount to the existence of the substantive right, and, like various initiatives promoting clean technology and fuels, only contribute to achieving adequate air standards.

Regrettably, the substantive right to breathe clean air does not appear in any binding instrument at the international level. Even though the right to breathe clean air has been indirectly mentioned-in the form of the right to a healthy environment-in the Stockholm, Rio, and Bizkaia Declarations, ${ }^{3}$ it has not found a place in any international treaty, nor has the United Nations General Assembly recognized it-unlike the right to clean water and sanitation. ${ }^{4}$ Likewise, the substantive right to breathe clean air exists only in theory at the national level—also in a form of the right to a healthy environment-as it is non-justiciable in the majority of states and its realization is only possible in conjunction with other human rights, such as the right to life and health. These and other problems surrounding the right to clean air, despite its paramount potential in combatting air pollution, do not allow for an easy apprehension of the right within the "hard" legal ambit yet. In the following sections, this Article will summarize all major conceptual shortcomings of the right to breathe clean air, starting with the provision of general uncertainties first and depicting those which undermine its status of a right next.

\section{B. General Perplexities of the Right to Breathe Clean Air \\ I. The Source of the Right: A Moral or Legal Right?}

One of the more confusing and difficult aspects of the right to breathe clean air pertains to its source as a human right, bringing the classical jurisprudential debate between natural and positive law to the forefront. Certainly, the paramount rationale for considering the right to clean air as a legal right is its inclusion in legal texts with a corresponding obligation of its protection by the states and the ability to rely on it in the courts. For instance, the second part of the German Basic Law (Germany's Constitution), "The Federation and the Länder," sets forth that, for the sake of future generations, the State shall protect natural foundations of life "by legislation and, in

\footnotetext{
${ }^{2}$ David R. Boyd, The Human Right to Breathe Clean Air, Annals of Glob. Health, Dec. 16, 2019, at 1 (2019).

${ }^{3}$ Principle 1 of the 1972 Stockholm Declaration on the Human Environment states that "Man [sic] has the fundamental right to freedom, equality and adequate conditions of life, in an environment of a quality that permits a life of dignity and wellbeing." U.N. Conference on the Human Environment, Declaration of the United Nations on the Human Environment, U.N. Doc. A/CONF.48/14/Rev.1 (June 16, 1972). Principle 1 of the Rio Declaration on Environment and Development provides that "human beings are at the centre of concerns for sustainable development. They are entitled to a healthy and productive life in harmony with nature." U.N. Conference on Environment and Development, Rio Declaration on Environment and Development, U.N. Doc. A/CONF.151/26/Rev.1 (Vol. I), annex I (Aug. 12, 1992). Article 1 of the Bizkaia Declaration recognizes that "everyone has the right, individually or in association with others, to enjoy a healthy, ecologically balanced environment." UNESCO General Conference, 30th Sess., Declaration of Bizkaia on the Right to the Environment, UNESCO Doc. 30 C/INF.11 (Sept. 24, 1999).

${ }^{4}$ See G.A. Res. 64/292, The Human Right to Water and Sanitation (July 28, 2010).
} 
accordance with law and justice, by executive and judicial action." 5 Similarly, Article 24 of the African Charter on Human and Peoples' Rights stipulates that "all people shall have the right to a general satisfactory environment [favorable] to their development." 6 The promotion and protection of this right is guaranteed by Article 30 of the same Charter, which established the African Commission on Human and Peoples' Rights to undertake this duty. ${ }^{7}$

The positivistic approach is not, however, the only one that makes the right to breathe clean air a human right. Admittedly, it also contains natural law underpinnings, which prescribe the right's universality, inalienability, and immunity to the non-existence of codified principles. As aptly remarked by Swanson and Hughes, "clean water and clean air are believed to be ours by birth; we somehow assume that such important and fundamental rights are protected by law." It thus remains beyond doubt that the source of the right to clean air has deeper roots than its recognition in legal acts, and the best evidence of that is the long-lasting cognizance thereof among different communities. ${ }^{9}$ The environmental and health conscience had surely transmogrified into a moral claim for a dignified life before the 1972 United Nations Conference on the Human Environment (UNCHE), which declared that "man has the fundamental right to freedom, equality and adequate conditions of life, in an environment of a quality that permits a life of dignity and well-being." 10 The travaux préparatoires of the Committee of the UNCHE corroborate that the need and conviction about the right to the adequate environment had already permeated the international community. ${ }^{11}$ In the same vein, the ethical importance of the basic human entitlement to clean air had certainly materialized in the Portuguese nation before 1976, when Portugal, as the first country, introduced to its constitution the "right to a healthy and ecologically balanced human environment." 12 The incidence of the moral right before its formal enactment is quite common and applies to different areas of human rights law. By way of comparison, the moral awareness and the ensuing struggle for granting voting rights to women, and the advocacy for abolishing slavery, both predate their formal acknowledgement in legislation. As Trajković propounds, there is no establishment of human rights without accepting moral values, which represent something durable and per se constitute the binding force of human rights. ${ }^{13}$ For this very reason, classical Bentham's legal theory of rights - which stipulates that only a substantive right is the child of law, ergo, a real right-suffers from conceptual and empirical drawbacks and can hardly be accepted

\footnotetext{
${ }^{5}$ Grundgesetz [GG] [BASIC LAw] art. 20a, translation at http://www.gesetze-im-internet.de/englisch_gg/index.html.

${ }^{6}$ Org. of African Unity [OAU], African (Banjul) Charter on Human and Peoples' Rights, O.A.U. Doc. CAB/LEG/67/3 (June $27,1981)$.

${ }^{7}$ In Social \& Economic Rights Action Centre \& the Centre for Economic \& Social Rights ("SERAP”) v. Nigeria, the African Commission ruled that the Nigerian government must take reasonable and other measures to prevent pollution and ecological degradation to promote conservation and to secure ecologically sustainable development to the Ogoni peoples affected by oil exploration in the Niger Delta region. SERAP v. Nigeria, Communication 155/96, African Commission on Human and Peoples' Rights [Afr. Comm'n H.P.R.] (May 27, 2002).

${ }^{8}$ Elizabeth Swanson \& Elaine Lois Hughes, The Price of Pollution: Environmental Litigation in Canada 205 (1990).

${ }^{9}$ See César Rodríguez-Garavito, A Human Right to a Healthy Environment? Moral, Legal and Empirical Considerations, in The Human Right to a Healthy Environment 156-63 (John H. Knox \& Ramin Pejan eds., 2018).

${ }^{10}$ U.N. Conference on the Environment, Declaration of the United Nations Conference on the Human Environment, U.N. Doc. A/CONF.48/14/Rev.1 (June 5-16, 1972).

${ }^{11}$ Rep. of the Preparatory Comm. on its Fourth Session, at 18, U.N. Doc. A/CONF.48/PC/17 (Mar. 15, 1972); see also Neil Popovic, In Pursuit of Environmental Human Rights: Commentary on the Draft Declaration of Principles on Human Rights and the Environment, 27 Colum. Hum. RTs. L. Rev. 487 (1996).

${ }^{12}$ David Boyd, The Environmental Rights Revolution: A Global Study of Constitutions 214 (2012). The African Charter was the first regional human right treaty to recognize the right to a satisfactory environment. See LOUIS J. KOTZÉ \& Anna Grear, Research Handbook on Human Rights and the Environment 405 (2015).

${ }^{13}$ See Marko Trajković, Moral Values as the Binding Force of the Human Rights, 63 AnNAls FAC. L. BELGRADE - BELGRADE L. REV. 127-40 (2015).
} 
within the framework of human rights law. ${ }^{14}$ Moreover, as some authors suggest, the standard court enforcement procedure is not necessary for the evidence and realization of the right, especially when one has in mind the moral right. ${ }^{15}$ Other strategies, involving the proliferation of information, activities of social movements, ethical tribunals, and local cooperation have likewise proved beneficial. Be that as it may, for the moment, it suffices to state that the right to clean air is both a moral and a legal human right. ${ }^{16}$

\section{The Category of Human Rights: A Third Generation Right?}

Further uncertainty has arisen as to the classification of the right to clean air. Downs put forward the assertion that a right to clean air-here as a component of the right to clean environmentshould be viewed as a third-generation right, on the basis that it is "necessary to facilitate the fulfilment of first and second-generation rights which already guarantee basic rights and freedoms." ${ }^{17}$ Vasak, who coined the term "solidarity rights," believes that the right to clean air belongs to this category, as it can only be achieved by common efforts of all who participate in society: States, individuals, and other private and public entities. ${ }^{18}$ Yet, both formulations do not withstand criticism. Namely, the third category of human rights might be classified as anachronistic, legacydevaluing true human rights that might cause additional confusion within the already complex system of human rights. It should also be noted that many scholars nowadays see the right to clean air as a fundamental human right, which is indispensable and interdependent. ${ }^{19}$ By the same token, the Inter-American Court on Human Rights, in its Advisory Opinion on the environment and human rights, regarded the right to clean air as a fundamental human right. ${ }^{20}$ In relation to the solidarity argument, one could rightly argue that the idea of solidarity is necessary for the attainment of all human rights, not only those rights which fall into the third category.

\section{Timescale: A Present-Day or Future Right}

Regarding the timescale, the focal point is whether the right to breathe clean air should be perceived only from the current, or also the future, perspective. National constitutions regulate this matter differently. For instance, while the South African Constitution in Article 24 guarantees the right to an environment that is not harmful to health and the well-being of present and future generations, many other constitutions do not refer explicitly to the future generations. In fact, jurisprudence and human rights discourse typically focus only on the rights of existing humans.

Nowadays, however, people tend to be more aware of the vulnerability of future generations to perils resulting from current environmental decision-making and are more focused on sustainable development and intergenerational equity. This is the correct standpoint, as it reflects the idea of

\footnotetext{
${ }^{14}$ For example, Bentham famously insisted that "natural rights is simple nonsense." JOHN BOWRING, THE WORKS OF JEREMY BENTHAM 523 (1843).

${ }^{15}$ See Rodríguez-Garavito, supra note 9, at 158; see also Amartya Sen, Elements of a Theory of Human Rights, 32 PHIL. \& Pub. AfF. 319-20 (2004).

${ }^{16}$ Lewis argues that the right to a healthy environment does not befit the scheme of natural law theory as it cannot be structurally linked with human dignity. See Bridgit Lewis, Quality Control for New Rights in International Human Rights Law: A Case Study of the Right to a Good Environment, 33 AusTL. Y.B. INT'L L. 55-80 (2016).

${ }^{17}$ Jennifer A. Downs, A Healthy and Ecologically Balanced Environment: An Argument for a Third Generation Right, 3 DUKE J. COMPAR. \& INT'L L. 352 (1993).

${ }^{18}$ Karel Vasak, Le droit international des droits de l'homme, in 140 COLleCted Courses of the HagUe ACADEMY OF INTERNATIONAL LAW 344-45 (1973).

${ }^{19}$ See Philip Alston, A Third Generation of Solidarity Rights: Progressive Development or Obfuscation of International Human Rights Law?, 29 Neth. INT'L L. ReV. 307-22 (1982); see also Joanna Kierzkowska, Prawo do powietrza wolnego od zanieczyszczeń $z$ "niskiej emisji”, in PraWa CzŁoWIEKa a OCHrona Środowiska-WSPÓlne WartośCI I WyzWANIA 209-12 (Bożena Gronowska ed., 2018).

${ }^{20}$ The Environment and Human Rights, Advisory Opinion OC-23/17, Inter-Am. Ct. H.R., (ser. A) No. 23, g5 (Nov. 15, 2017).
} 
the preservation and continued use of res communis omnium. ${ }^{21}$ The U.S. scholars have of late advanced a new so-called "atmospheric trust theory" that relies on the ongoing Juliana $v$. United States of America lawsuit claiming that generations to come have the right to a clean atmosphere. ${ }^{22}$

Yet, the reference to future generations should be construed as a duty of those who are alive rather than as a right of those who still have not acquired the right. Such a duty can, inter alia, be exercised in court litigation, as noted by the Supreme Court of the Philippines. Having recognized the standing of forty-four children who opposed cutting the rainforest via their logging permits, the court observed that their "assertion of the right to a sound environment constitutes, at the same time, the performance of their obligation to ensure the protection of that right for the generations to come." 23

Consequently, the right to breathe clean air should be construed as a right of the present generation, which implies a constant duty towards persons not yet born.

\section{An Individual or Collective Right?}

Another aspect related to the right to breathe clean air is whether it should be considered as an individual right — owed to a person — or a collective right—owed to all people or humankind-. Even though it virtually does not exist as a separate right, the parallel can, again, be drawn to the right to a healthy environment. As mentioned, Article 24 of the African Charter indicates that "all people shall have the right to a general satisfactory environment" which assumes a collectivist approach. The right to the atmosphere (aër in Greek and Latin) has been categorized as one of the legal commons since Roman times. The Institutes of Emperor Justinian proclaimed that "[b]y the law of nature, things can be everybody's: these things which are naturally common to all are the air, flowing water, the sea and the seashores." ${ }^{24}$ With regard to draft guideline 3 discussed by the Sixth Committee of the General Assembly at its seventy-first session, the Polish delegation proposed that the last sentence of paragraph (7) of the commentary to draft guideline 3 should be replaced with the following phrase: "In this context, it should be noted that not only is the Paris Agreement acknowledging in the Preamble that climate change is a common concern of humankind, but also that ambient air quality is a common concern of humankind, according to [World Health Organization] Ambient Air Quality Standards and Guidelines."25 Humankind as a whole is thus the recipient of the protection. ${ }^{26}$ Nowadays, the collective standpoint gains prominence, although there are authors who still tend to consider the right to clean air as an individual right. ${ }^{27}$ In fact, the majority of states' constitutions provide for individualized rights, but the examples of collective rights are not uncommon. ${ }^{28}$ The most appropriate answer

\footnotetext{
${ }^{21}$ See Andreja Mihailović, Pravo na zdravu životnu sredinu kao intergeneracijski fenomen, 66 ANNALS FAC. L. BELGRADE BELGRAde L. REV. 236-55 (2018).

${ }^{22}$ This theory connects aspects of the public trust doctrine and state responsibility. See. J.B. Ruhl \& Thomas McGinn, The Roman Public Trust Doctrine: What Was It, and Does It Support an Atmospheric Trust?, 47 EcologY L.Q. 117 (2019).

${ }^{23}$ Minors Oposa v. Sec'y of the Dep't of Env't \& Nat. Res., 33 ILM 173, 185 (S.C. July 30, 1993) (Phil.).

${ }^{24}$ Peter Birks \& Grant Mcleod, Justinian's Institutes, 55 (1987).

${ }^{25}$ Int'l L. Comm'n, Rep. on the Work of Its Seventy-First Session, at 8, U.N. Doc. A/C.6/71/SR.26 (Oct. 28, 2016).

${ }^{26}$ See Laura Horn, The Implications of the Concept of a Common Concern of Human Kind on a Human Right to a Healthy Environment, Macquarie J. INT'L L. \& Compar. ENV'T L. 244-50 (2004); Shinya Murase (Special Rapporteur), Fifth Rep. on the Protection of the Atmosphere, U.N. Doc. A/CN.4/711. (Feb. 8, 2018).

${ }^{27}$ See Bridget A. Lewis, Environmental Human Rights and Climate Change Current Status and Future Prospects 15-39 (2018).

${ }^{28}$ Kenya's Constitution in Article 42 reads "every person has the right to a clean and healthy environment." CONSTITUTION art. 42 (2010) (Kenya). In contrast, the Constitution of the Democratic Republic of Congo in Article 53 reads "all persons have the right to a healthy environment.” DEM. REP. CONGo CONST., art. 53; see also Erin Daly \& Richard May, Learning from Constitutional Environmental Rights, in The Human Right to a Healthy Environment 52 (John H. Knox \& Ramin Pejan eds., 2018).
} 
to the posited question would, therefore, be that, although the right may protect people individually, it also requires collective action and cooperation, and thus possesses both dimensions.

\section{The Correlation Between a Substantive Right and Procedural Rights}

The next aspect concerns the need to articulate the differences between the substantive right to clean air and other correlated procedural rights. Although there exists a temptation in conflating both aspects in line with the "expansive approach" put forward by Rodriguez-Rivera, it must be observed that procedural rights constitute a separate corpus of rights, which, in truth, exert a substantial impact on the realization of the said right. ${ }^{29}$ David Boyd, UN Special Rapporteur on "the Issue of human rights obligations relating to the enjoyment of a safe, clean, healthy and sustainable environment" outlined in his report the catalog of procedural rights. The catalog includes the right to education and initiatives that raise awareness on air quality and related problems; access to environmental information; freedom of expression, association, and assembly; participation in the assessment of proposed projects, policies, and environmental decisions; and affordable, timely access to remedies. ${ }^{30}$ Recent trends of restricting the activities of externally funded NGOs or targeting environmental defenders in developing countries impair the achievement of environmental justice, the protection of the substantive right to clean air, and the environmental rule of law in general.

Procedural environmental rights are present in national and international regulations. To date, more than thirty national constitutions have included multiple procedures aimed at securing environmental protection. Article 35(2) of the Czech Republic's Constitution, for example, stipulates that "everybody is entitled to timely and complete information about the state of the environment and natural resources." ${ }^{31}$ At the international level, procedural environmental rights are enshrined in such documents as the Rio Declaration on Environment and Development, ${ }^{32}$ the Convention on Access to Information, Public Participation in Decision-Making and Access to Justice in Environmental Matters (Aarhus Convention), which, apart from individuals, is also addressed to associations, ${ }^{33}$ and the EU Air Quality Directive. Sommermann's study has shown that the Aarhus Convention belongs to one of the most frequently quoted international treaties in administrative law decisions of domestic courts in Europe. ${ }^{34}$ The implementation of judicial review standards - such as the availability of procedures, their adequacy, costs, and timeliness - turned out to be the most problematic point for states. ${ }^{35}$

It is not uncommon that while establishing a violation of the substantive right, adjudicating bodies refer to procedural rights. For instance, in Social and Economic Rights Action Centre and the Centre for Economic and Social Rights (SERAP) v. Nigeria, the African Commission, besides establishing a Nigerian violation of the right to a satisfactory environment (Article 24 of the ACHPR), noted that Nigeria failed to conduct a social and environmental impact assessment, inform people about health and environmental risks, or include those concerned with decision-making bodies. ${ }^{36}$

\footnotetext{
${ }^{29}$ Luis Rodriguez-Rivera, Is the Human Right to Environment Recognized Under International Law? It Depends on the Source, 12 DenV. J. INT'L L \& POL'Y 16 (2001).

${ }^{30}$ U.N. Special Rapporteur, Rep. on the Issue of Human Rights Obligations Relating to the Enjoyment of a Safe, Clean, Healthy and Sustainable Environment, 59, U.N. Doc. A/HRC/40/55 (Jan. 8, 2019) [hereinafter Report of the U.N.].

${ }^{31}$ Ústavní zákon č. 1/1993 Sb., Ústava České Republiky [Constitution of the Czech Republic], art. 35(2).

${ }^{32}$ U.N. Conference on Environment and Development, Rio Declaration on Environment and Development, U.N. Doc. A/CONF.151/26/Rev.1 (Vol. I), annex I (Aug. 12, 1992).

${ }^{33}$ Convention on Access to Information, Public Participation in Decision-Making and Access to Justice in Environmental Matters, June 25, 1998, 2161 U.N.T.S. 447.

34"In France, the Conseil d'État has referred to the Aarhus Convention in 71 judgements since 2004, in Italy the Consiglio di Stato and the Tribunali Amministrativi Regionali referenced it in 107 decisions." Karl-Peter Sommermann, Transformative Effects of the Aarhus Convention in Europe, 77 ZAÖRV 321-23 (2017).

${ }^{35} I d$. at 329.

${ }^{36}$ See Rachel Murray, the African Charter on Human and Peoples’ Rights: A Commentary 555-56 (2019).
} 
Irrespective of such intermingling practices, it is necessary to note that apart from the African Continent and a handful of states, the right to breathe clean air - in the form of a right to a healthy environment - is nonjusticiable, and it is actually procedural rights that largely contribute to environmental protection instead. Nevertheless, it remains highly disputable whether procedural rights are sufficient to ensure a healthy and ecologically sound environment. ${ }^{37}$ Shelton argues that an independent right to breathe clean air is indispensable. ${ }^{38}$ The recognition of the substantive right would add to environmental protection by placing limits "on the outcome of the process." 39 The substantive right to breathe clean air would, therefore, guard against such situations when policy decisions - even in keeping with procedural guarantees-would be insufficient in securing human and environmental health. In other words, it would be a minimum enforceable guarantee of environmental quality.

One can thus postulate that both substantive and procedural rights are needed, although procedural rights might be especially helpful in resolving conflicting situations. For example, procedural rights can be used as a balancing power between the substantive right to breathe clean air and other competing human rights, such as the rights to development, private property, or food.

\section{Specific Problems of the Right to Breathe Clean Air: Can We Talk About the Right? \\ I. Autonomy: Part of a Greater Structure and the Interrelationship with Existing Human Rights}

Possibly the most important issue revolving around the right to clean air is its autonomy. Indeed, apart from a handful of acts, such as the Constitution of Pennsylvania and the Constitution of Massachusetts, the right to clean air virtually does not exist as a stand-alone provision, whether in national constitutions or international legislation. ${ }^{40}$ The right to clean air is conventionally conceptualized as a component of the broader right to healthy, clean, or ecologically balanced human environment-along with the right to safe water and sanitation, healthy and sustainable food, a safe climate, and healthy biodiversity and ecosystems. ${ }^{41}$ The words "healthy," "clean," "sound," and "ecologically balanced" shall be construed as synonyms and are often used interchangeably. For instance, the Argentine Constitution in Article 41 provides that residents "enjoy the right to a healthy, balanced environment," 42 the Mongolian Constitution in Article 16 refers to the "right to a healthy and safe environment," 43 Article 23 of Montenegro's Constitution stipulates that "everyone shall have the right to a sound environment," 44 and Article 30 of Nepal's Constitution sets forth that "every citizen shall have the right to live in a clean and healthy environment. " ${ }^{5}$

\footnotetext{
${ }^{37}$ See Alan Boyle, Human Rights and the Environment: Where Next?, 23 Eur. J. INT'L L. 621-27 (2012).

${ }^{38}$ Although she referred to the right to a clean environment, the analogy is equally applicable to the right to clean air as well. Dinah Shelton, Developing Substantive Environmental Rights, J. HUM. RTs. \& ENV'T 91 (2010).

${ }^{39}$ Donald Anton \& Dinah Shelton, Environmental Protection \& Human Rights 436 (2011).

${ }^{40}$ Article 1, Section 27 of the Pennsylvania Constitution provides: "The people have a right to clean air, pure water, and to the preservation of the natural, scenic, historic and esthetic values of the environment." PA. ConST. art. I, $\$ 27$. Article XLIX of the Massachusetts Constitution sets forth: "The people shall have the right to clean air and water, freedom from excessive and unnecessary noise, and the natural, scenic, historic, and esthetic qualities of their environment.” MASs. CONST. art. XLIX.

${ }^{41}$ The Ksentini Report offers what may be the broadest definition of environmental rights. These rights, inter alia, include a) freedom from pollution, environmental degradation, and activities that threaten life, well-being, or sustainable development; b) protection and preservation of the air, soil, water, sea-ice, flora, and fauna; c) the highest attainable standards of health; d) ecologically sound access to nature and the conservation and the use of nature and natural resources; and e) preservation of unique sites. See U.N. Special Rapporteur (Special Rapporteur on Prevention of Discrimination and Protection of Minorities), Final Rep. of Special Rapporteur, at 74-76, U.N. Doc. E/CN.4/Sub.2/1994/9 (Jul. 6, 1994).

${ }^{42}$ Art. 41 , Constitución Nacional [CONST. NAC.] (Arg.).

${ }^{43}$ Mong. CONST. art. 16.

${ }^{44}$ Montenegro Const. art. 23.

${ }^{45}$ Nepal Const. art. 30; see also James R. May \& Erin Daly, Global Judicial Handbook on EnVironmental Constitutionalism 19-20 (3d ed. 2019).
} 
Although it holds true that such taxonomy neither makes the right to clean air less of a fundamental human right than other components nor impossible to distil from the broader structure, it stands to reason that the right would acquire a clearer meaning and avoid potential misinterpretations if it was articulated separately. Because most of the constitutions refer to the cluster right of "a healthy environment," it is unlikely that they will redefine their approach and secure individual articles for each component of the cluster right in their supreme legal acts. New laws, however may specifically invoke the right to clean air, as is the case with the New York State Constitution, where the proposed constitutional amendment S 2072/A 2064 inserted a new Section 19, recognizing the inalienable and self-executing right of New Yorkers to clean air. ${ }^{46}$ In a similar way, at the international level, where the right has not been recognized yet, the UN Special Rapporteur for the first time dissociated more patently the right to clean air from the right to a healthy environment in his last 2019 report. ${ }^{47}$

The question of the autonomy of the right to breathe clean air arises also in relation to its interdependence with other human rights. This is particularly evident in adjudication, as courts tend to subsume the right to breathe clean air under the right to life or the right to health. In Subhash Kumar v. State of Bihar, the Supreme Court of India ruled that the right to life is a fundamental right under Article 21 of the Indian Constitution and includes "the right of enjoyment of pollution-free water and air for full enjoyment of life." ${ }^{\prime 8}$ The Nepalese and Pakistani Supreme Courts took a similar position, ruling that environmental rights are embedded within the constitutional right to life. ${ }^{49}$ In Europe, the European Court of Human Rights (ECtHR) - given the absence of the right to clean air (a healthy environment) in its European Convention on Human Rights-has often interlinked the right to clean air with other Convention's rights, especially the right to life (Article 2), the right to private and family life (Article 8), the right to an effective remedy (Article 13), and the right to peaceful enjoyment of possessions (Article 1 of Protocol No. 1). In Oneryildiz v. Turkey, a case concerning a methane explosion on April 28, 1993 near the Ümraniye municipal rubbish tip which caused the death of thirty-nine people, the ECtHR ruled that Article 2 imposes "a positive obligation on States to take appropriate steps to safeguard the lives of those within their jurisdiction." ${ }^{\circ}$ In Fadeyeva $v$. Russia, the Court established the violation of the right to private and family life and ruled that there was "sufficient nexus between the pollutant emissions and the State," ergo, that Russian authorities had not undertaken adequate measures to secure the dignified life of people living around the Severstal steel plant. ${ }^{51}$ In the most recent case, Portillo Cáceres and Others v. Paraguay, the UN Human Rights Committee, a quasi-adjudicatory body, ruled that the mass use of agrotoxins by large agribusinesses in Paraguay — which had led to poisoning and death of the affected population — violated their rights to life, privacy, family, home, and to an effective remedy. ${ }^{52}$ As observed by the Committee, although the right to breathe clean air is not enumerated in the International Covenant on Civil and Political Rights (ICCPR), "implementation of the obligation to respect and ensure the right to life, and in particular life with dignity, depends, inter alia, on measures taken by State parties to preserve the environment and protect it against harm, pollution and climate change." ${ }^{\prime 3}$ The Committee stressed that there exists an "undeniable link" between environmental protection and human rights. ${ }^{54}$

\footnotetext{
${ }^{46}$ The current status of the bill can be found under https://www.nysenate.gov/legislation/bills/2019/s2072.

${ }^{47}$ Report of the U.N., supra note 30.

${ }^{48}$ Subhash Kumar v. State of Bihar, (1991) AIR 1991 SC 420 (India).

${ }^{49}$ In Re Hum. Rts. Case (Env't Pollution in Baluchistan), (1992) PLD 1994 (SC) 102 (Pak.); Suray Prasad Sharma Dhungel v. Godavari Marble Indus., Supreme Court of Nepal, WP 35/1992 (Oct. 31, 1995).

${ }^{50}$ Oneryildiz v. Turkey, App. No. 48939/99, 79 (Nov. 30, 2004) https://hudoc.echr.coe.int/app/conversion/pdf/?library= ECHR\&id=002-4094\&filename=002-4094.pdf.

${ }^{51}$ Fadeyeva v. Russia, App. No. 55723/00, at 376, (Sept. 6, 2005) http://hudoc.echr.coe.int/eng?i=001-69315.

${ }^{52}$ Portillo Cáceres and Others v. Paraguay, Judgment U.N. Hum. Rts. Comm., U.N. Doc. CCPR/C/126/D/2751/2016 (Sept. 20, 2019).

${ }^{53}$ U.N. Hum. Rts. Comm., International Covenant on Civil and Political Rights, General Comment No. 36, 62, U.N. Doc. CCPR/C/GC/36 (Sept. 3, 2019).

${ }^{54}$ Subhash Kumar, AIR 1991 SC 420.
} 
In truth, it is also possible to approach the correlation between clean air and other human rights from another, opposite perspective. Namely, that the exercise of human rights is essential to achieving good air quality. ${ }^{55}$ When the people who may be affected by activities and proposed policies can freely participate in the environmental decision-making process, their societies are much more likely to have strong environmental protections. In other words, the unimpaired enjoyment of human rights, including the right to information, education, access to justice, as well as the freedom of assembly and expression, are vital to securing and maintaining adequate air quality. ${ }^{56}$

Being both a part of the cluster right and substantially correlated with other human rights is one of the greatest challenges to the "individuality," or "purity," as Collins suggests, and, by implication, to the normativity of the right to clean air. Following Collins, the right in its "pure" sense should be able to create entitlements beyond those contained in other existing rights. ${ }^{57}$ Thus, in a hypothetical scenario when a polluting factory causes harm or death to people, the concerned people should be in a position to rely not only upon the well-established right to life-and the duty of the state to protect and promote life-but also invoke the infringement of an independent, free-standing right to breathe clean air.

\section{The Ambiguous Content of the Right (I): How "Healthy"?}

The content of every right should have a clear meaning, outline the juridical scope, and identify right-holders and duty-bearers. Unfortunately, the right to clean air certainly does not belong to the corpus of rights with substantial legal clarity and certainty. Inasmuch as the definition of air does not raise concerns - it is the gas mixture that forms the Earth's atmosphere- the question of what "adequate quality" means, and who should determine it, remains disputed. Namely, should adequate quality be left to the domestic legislator or should it be determined at the international level? More importantly, should it be solely based on scientific data or should socio-economic determinants be considered as well?

The elementary definition of adequate air quality, from an anthropocentric perspective, would mean that the air should be healthful, fulfilling human rights standards. Following Bryner, a clean or healthy, ergo, adequate, air presupposes the absence of pollution-which would compromise ecological integrity or threaten irreversible harm. At a minimum, it must be "sufficient for human life, food production and to maintain the ecosystem services and biological diversity that are familiar to humans." 58

Providing a more sophisticated or technical definition of decent air quality is highly challenging. Given that countries and international organizations invoke different standards related to air pollution limits, the question surfaces whether it is at all possible to conclusively state what clean air means, a fortiori, whether the right to clean air is universally applicable. For example, the new EU Air Quality Directive sets out the annual level for particulate matters $P_{2,5}$ at $25 \mu \mathrm{g} / \mathrm{m}^{3}$ and $\mathrm{PM}_{10}$ at $40 \mu \mathrm{g} / \mathrm{m}^{3}$, ${ }^{59}$ while the World Health Organization guidelines prescribe the annual limits for $\mathrm{PM}_{2,5}$ to be $10 \mu \mathrm{g} / \mathrm{m}^{3}$ and for $\mathrm{PM}_{10} 20 \mu \mathrm{g} / \mathrm{m}^{3}{ }^{60}$ Similar disparities relate to the allowed

\footnotetext{
${ }^{55}$ Dinah SHelton, Human Rights, Health \& Environmental Protection: Linkages in Law \& Practice, in U.N. HEALTH AND Human Rights Working Paper Series No. 1 (2002).

${ }^{56}$ See John H. Knox (Special Rapporteur), Rep. of the Special Rapporteur on the Issue of Human Rights Obligations Relating to the Enjoyment of a Safe, Clean, Healthy and Sustainable Environment, U.N. Doc. A/HRC/37/59, Annex (Jan. 24, 2018).

${ }^{57}$ See Lynda Collins, Are We There Yet? The Right to Environment in International and European Law, 3 MCGILL J. SuSTAINABLE DEV. L. 148 (2007).

${ }^{58}$ Nicholas Bryner, A Constitutional Right to a Healthy Environment, in RESEARCH HANDBOOK ON FUNDAMENTAL COnCEPT OF EnVironmental LAw 172 (Douglass Fisher ed., 2016).

${ }^{59}$ Council Directive 2008/50/EC of May 21, 2008, On Ambient Air Quality and Cleaner Air for Europe, Annexes XI, XIV 2008 O.J. (L 152) 1 (EC).

${ }^{60}$ World Health Org. [WHO], Air quality guidelines for particulate matter, ozone, nitrogen dioxide and sulphur dioxide (Global update 2005), at 9, WHO Doc. WHO/SDE/PHE/OEH/06.02 (2005), https://apps.who.int/iris/bitstream/handle/ 10665/69477/WHO_SDE_PHE_OEH_06.02_eng.pdf.
} 
concentration of other air pollutants, such as ozone, sulphur dioxide, nitric oxide, mercury, and others-as well as the time allowance for the excess. ${ }^{61}$ It is particularly worrying that eighty states have no air quality standards and guidelines at all—which, in consequence in their cases-may lead to total obfuscation of the term "clean." 62

What further obscures a common content of the right to clean air is the creation of groups, which require particular care, and hence, better air quality. In his recent report, the UN Special Rapporteur underlined that women, children, the elderly, and indigenous peoples are particularly affected by bad quality air. ${ }^{63}$ This essentially means that for various people, differing levels of air quality are considered "decent."

\section{The Ambiguous Content of the Right (II): Primary and Secondary Subjects}

The right to breathe clean air does not have specified recipients. It is, therefore, possible to approach the question of its subjects from two angles: Anthropocentric, claiming that only human beings are the holders of the right, and ecocentric, presupposing a wider range of living species.

Nevertheless, it stands to reason that human beings are the primary recipients of the right to breathe clean air. The anthropocentric thesis of the right to clean air is insofar valid as the limits set out in legal regulations are adjusted to human needs and humans are allowed to seek redress if the right is violated. ${ }^{64}$ For instance, the Romanian Constitution recognizes "the right of every person to a healthy, well-preserved and balanced environment." 65

Yet, the very phrase "well-preserved and balanced" may imply the duty of not causing harm by pollution to other living organisms. This is patently underscored in Angola's Constitution, which calls on the state to "adopt measures necessary for the protection of the environment and the species of flora and fauna" and to "maintain ecological equilibrium." 66 Against this background, it is reasonable to assume that other living species, such as animals, are likewise addressees of the right to breathe clean air. ${ }^{67}$ They could, though, be defined as secondary subjects. $^{68}$

With reference to legal acts that appertain to the secondary subjects of the right to clean air, one could mention the EU Air Quality Directive, which, in Article 1, aims at "defining and establishing objectives for ambient air quality designed to avoid, prevent or reduce harmful effects on human health and the environment as a whole." In the same spirit, the Rio Declaration on Environment and Development, the 2030 Agenda for Sustainable Development, and the Paris Agreement all highlight that "social and economic development depends on the sustainable management of [the] planet's natural resources" and that the proper protection of biodiversity, ecosystems, and wildlife is needed. ${ }^{69}$ The Heads of State and Government and High Representatives, while deciding on seventeen new global Sustainable Development Goals, declared that they wish for a world where "humanity lives in harmony with nature and in which wildlife and other living

\footnotetext{
${ }^{61}$ See The Law Libr. of Cong.'s Glob. Legal Res. Directorate, Rep. on Regulation of Air Pollution (June 2018), https://www. loc.gov/law/help/air-pollution/regulation-of-air-pollution.pdf.

${ }^{62}$ Report of the U.N. supra note 30 , at 12.

${ }^{63} \mathrm{Id}$. at 6 .

${ }^{64}$ Notably, human beings entrusted with the right to clean air are sometimes differently identified in national jurisdictions, and acts offer environmental protection to residents, women, children, and indigenous populations.

${ }^{65}$ Rom. CONST. art. 35(1) (1991).

${ }^{66}$ ANGL. CONST. art. 39(2) (2010).

${ }^{67}$ That animals increasingly become bearers of rights confirms a recent case of a dog, Jack, who was compensated for a canceled flight. See Wladyslaw Czapliński, Recognition and International Legal Personality of Non-State Actors, PÉCS J. INT'L \& EUR. L. 8 (2016).

${ }^{68}$ See Catherine Redgwell, Life, the Universe and Everything: A Critique of Anthropocentric Rights, in HUMAN RIGHTS \& Approaches to Environmental Protection 83-86 (Alan Boyle \& Michael Anderson eds., 1996).

${ }^{69}$ G.A. Res. 70/1, Transforming our World: The 2030 Agenda for Sustainable Development, at 9 (Sept. 25, 2015).
} 
species are protected." 70 The "wildlife," "ecosystems," and "livelihoods" thereby become subjects of international concern and enjoy the protection against contaminated air. Certain countries, like New Zealand or India, have even recognized intrinsic rights of nature, conferring legal personhood upon the Te Urewera National Park and the Ganges River respectively, which means that their rights are legally protected and can be vindicated. ${ }^{71}$ Thus, although human beings remain the basic subjects of the right to breathe clean air, other living organisms benefit from the right as well.

However, the more pertinent aspect which impinges on the normative status of the right is the lack of clear ascertainment of duty-bearers and right-holders in potentially contentious cases. The Constitution of Serbia provides that "everyone shall have the right to a healthy environment" and that "everyone, especially the Republic of Serbia and autonomous provinces, shall be accountable for the protection of environment." ${ }^{\prime 2}$ Within traditional human rights framework, it is usually a state that is obliged to guarantee and respect human rights. ${ }^{73}$ With respect to the right to breathe clean air, the catalog of duty-bearers appears to be larger, while their responsibility is lessened in view of the vague temporal obligations and the possibility of a multiplicity of culprits. Moreover, if the right to breathe clean air was considered individually, without recourse to other human rights, then the class of potential claimants would likewise be broad, and, as aptly observed by Lewis, "it would be difficult to identify a person or group with a sufficient interest in the environmental harm to bring a claim" when environmental harm occurs. ${ }^{74}$ Therefore, the relationship between the duty-bearers and rightholders seems to be quite unsettled.

\section{The Ambiguous Content of the Right (III): The Scope of the Right}

The determination of the geographical scope of the right to clean air is complicated. In particular, it is not clear whether the right to clean air is an international, or mainly a regional or national right. The main argument for rejecting universality to the right to clean air, in the positivist sense, is that it still has not been recognized by the United Nations as a universal right. ${ }^{75}$ Namely, neither basic human right documents, such as the 1948 Universal Declaration of Human Rights or 1966 UN Covenants on Human Rights, nor any other subsequent treaty, mention it - either as an autonomous right or as a part of the right to a healthy environment. It is also debatable whether the right has acquired the customary international law character, as there has been very little in the way of consistent state practice. ${ }^{76}$ As the UN Environment report found, despite a thirty-eightfold increase in environmental laws since 1972, a failure to fully implement and enforce these laws is readily evident. ${ }^{77}$ The inductive method informing the formation of an international custom also fails on account of opinio juris, which is the conviction that custom is mandatory. The absence of the right to clean air at the international level confirms that states are quite resistant in taking up such a new obligation and prefer to consider it under a domestic, often non-justiciable, legal

\footnotetext{
${ }^{70} I d$. at 3. Similarly, the Paris Agreement in Article 7 urges for the "long-term global response to climate change to protect people, livelihoods and ecosystems.” U.N. Conference of the Parties, Rep. of the Conference of the Parties on Its Twenty-First Session, at 26, U.N. Doc. FCCC/CP/2015/10/Add.1 (Jan. 29, 2016).

${ }^{71}$ See Te Urewera Act 2014, s 11 (N.Z.). The High Court in the Northern Indian state of Uttarakhand ruled in March 2017 that Ganges and Yamuna have "all corresponding rights, duties and liabilities of a living person." Lalit Miglani v. State of Uttarakhand (2017) (India).

${ }^{72}$ Const. of THE Republic OF Serb. art. 74 (2006).

${ }^{73}$ LEWIS, supra note 27 , at 74 .

${ }^{74} I d$. at 75.

${ }^{75}$ See Günther Handl, The Human Right to a Clean Environment and Rights of Nature, in THE CAMBRIDGE HANDBOOK OF New Human Rights Recognition, Novelty, Rhetoric 137-53 (Andreas von Arnauld, Kerstin von der Decken \& Mart Susi eds., 2020).

${ }^{76}$ LEWIS, supra note 27 , at 60.

${ }^{77}$ UNEP, Environmental Rule of Law: First Global Report, at 33 (Jan. 2019), https://wedocs.unep.org/bitstream/handle/20. $500.11822 / 27279 /$ Environmental_rule_of_law.pdf ?sequence=1\&isAllowed $=\mathrm{y}$.
} 
framework. ${ }^{78}$ Therefore, the postulates of some authors trying to attribute the customary law character to the right - by studying the implantation of the environmental impact assessment (EIA) in the world ${ }^{79}$ — or even arguing that it is becoming a jus cogens norm (binding upon the whole international community), are excessive and perhaps even misleading. ${ }^{80}$ On the one hand, it is probably best to say that the right to clean air in the positivist meaning is yet to emerge at the international level. On the other hand, the right to clean air certainly exist globally as natural law, as noted in the preceding section.

In view of that, it must be assumed that the right to clean air predominantly boils down to a national level. However, as mentioned, the right at a national level, if it exists, is not meaningfully adhered to. This then raises the question as to whether the right even has a proper domestic law character. ${ }^{81}$

Another relevant question pertains to the sphere of the right to breathe clean air, most notably, whether the right applies only outdoors or also indoors. In the majority of cases, the air is comprehensively protected only in the public sphere, in spite of the evidence that indoor pollution is likewise very dangerous to human health and generates high economic costs. ${ }^{82}$ For example, the EU Air Quality Directive regards only ambient air quality, stipulating that workplaces are excluded from its scope, "where provisions concerning health and safety at work apply and to which members of the public do not have regular access." ${ }^{83}$ Similarly, the Serbian Law on Air Protection sets forth that the air should be construed as the air in the troposphere in the open spaces, excluding closed areas. ${ }^{84}$ Consequently, the indoor air is either only protected by the employer, educational institution, or another establishment-or, in the case of private houses -is not subject to any protection at all. In the latter instance, members of the household, including children, can hardly assert the right to breathe clean air, especially if people smoke in the house or use stoves fueled by kerosene, biomass (wood, animal dung, and crop waste), or coal. Fortunately, in recent years there is a growing tendency of extending legal protection to people, especially children, from indoor air pollution. The prohibition of smoking in restaurants and the Australian Public Health (Tobacco) Act 2008, which forbids smoking in a car with a child under sixteen years of age, are good examples thereof.

\section{The Enforcement Conundrum}

The enforcement of the right to clean air is undoubtedly one of the weakest sides of the right. At the international level, the right remains unenforced, for the simple reason that there still exists no right to clean air on the international level — which could be subject to the scrutiny of specially entrusted

\footnotetext{
${ }^{78}$ See Rhuks Ako, Ngozi Stewart \& Eghosa O. Ekhator, Overcoming the (Non)justiciable Conundrum: The Doctrine of Harmonious Construction and the Interpretation of the Right to a Healthy Environment in Nigeria, in JUSTICIABILITY OF Human Rights Law in Domestic Jurisdictions 123-41 (Alice Diver \& Jacinta Miller eds., 2015).

${ }^{79}$ See, e.g., Rebecca M. Bratspies, Reasoning Up to Human Rights: Environmental Rights as Customary International Law, in The Human Right to a Healthy Environment 122-35 (John H. Knox \& Ramin Pejan eds., 2018).

${ }^{80}$ See Loius Kotzé, In Search of a Right to a Healthy Environment in International Law, in THE HUMAN RIGHT TO A Healthy Environment 136-54 (John H. Knox \& Ramin Pejan eds., 2018); see also the Order of the German Federal Constitutional Court, which considered, among other things, environmental protection as a peremptory norm. BVERFGE, 2 BvR 955/00, Oct. 26, 2004, https://www.bundesverfassungsgericht.de/SharedDocs/Entscheidungen/EN/2004/10/ rs20041026_2bvr095500en.html.

${ }^{81}$ It is often subjected to conflicting constitutional provisions or particular national policies. See MAY \& DALY, supra note 45 , at $49-50$.

${ }^{82}$ See World Bank Grp. [WBG], The Cost of Air Pollution Strengthening the Economic Case for Action, at 35-36 (2013), http:// documents.worldbank.org/curated/en/781521473177013155/pdf/108141-REVISED-Cost-of-PollutionWebCORRECTEDfile.pdf; see also Arnold W. Reitze, Jr. \& Sheryl-Lynn Carof, The Legal Control of Indoor Air Pollution, 25 B.C. EnV’T AfF. L. REV. 247-345 (1998).

${ }^{83}$ Council Directive 2008/50/EC, art. 2, 2008 O.J. (L 152) 1 (EC).

${ }^{84}$ Air Protection Act, Off. Gazette of the Rep. of Serb. No. 36/09; Amends. to the Law on Air Protection, Off. Gazette of the Rep. of Serb. No. 10/2013 art. 3.
} 
supervisory bodies. Yet, the right can be executed in a different "international" context, especially as a state's responsibility for causing environmental harm - in this case, a State serves as an agent of the people concerned. The milestone case in that regard is the Trail Smelter case between the United States and Canada, then a dominion of the United Kingdom, decided by the Arbitral Tribunal. ${ }^{85}$ The award established the pecuniary responsibility of the Consolidated Mining and Smelting Company (COMINCO), whose smoke had caused damage to forests and crops in the area surrounding Washington. The arbitration not only coined the polluter pays principle (PPP) in international law, but also affirmed the customary principle of "good neighborliness" in bilateral arrangements between neighboring states. ${ }^{86}$ With time, state obligations associated with the maxim sic utere tuo ut alienum non laedas (use your own property in such a manner as not to injure that of another) changed the focus from monetary compensation to prevention: Due diligence, environmental impact assessment, equitable and reasonable utilization of the atmosphere, and international cooperation. ${ }^{87}$ This is predominantly so because compensation in case of harm often "cannot restore the situation prevailing prior to the event or accident. ${ }^{\text {" } 88}$

Unfortunately, states are rarely held accountable for not obeying international environmental law principles which are conducive to securing clean air, both for legal and factual reasons. First and foremost, states have proved to be extremely resistant in submitting environmental law to the compulsory jurisdiction of a court; states need to agree for a court to resolve a potential dispute. Furthermore, the scope of such a dispute would be virtually limited to adjacent territories as it is very difficult to prove the responsibility of a State for long-distance air pollution. Also, given the enhanced contribution of private businesses to environmental degradation, it remains unclear what type of liability should be attributed to states, and in particular, whether it should be liability ex delicto, liability sine delicto stricto sensu, or liability sine delicto lato sensu. ${ }^{89}$ Over and above, the international treaty regime concerning long-distance pollution is very fragmented. State obligations are, inter alia, reflected in the Geneva Convention on Long-Range Transboundary Air Pollution (CLRTAP) and protocols thereto, the Association of Southeast Asian Nations (ASEAN) Agreement on Transboundary Haze Pollution, and the International Convention for the Prevention of Pollution from Ships (MARPOL), which concentrate on cooperative and facilitative measures rather than enforcement procedures. Even the potential treaty on air protection, on which the ILC is currently working, will produce little coercive enforcement effectiveness, in view of the fact that states decided to exclude from its scope such matters as "the liability of states and their nationals, the polluter-pays principle, the precautionary principle, common but differentiated responsibilities, and the transfer of funds and technology to developing countries, including intellectual property rights." ${ }^{\prime 0}$ Therefore, it is not difficult to agree with Yamineva that international law fails to adequately address air pollution and secure the human right to clean air. ${ }^{91}$

\footnotetext{
${ }^{85}$ Trail Smelter Case (United States v. Canada), Judgment U.N. Arbitral Trib., 3 U.N. Rep. Int'l Arb. Awards 1905 (1941).

${ }^{86}$ The Smelter case relied heavily on a domestic case in the United States initiated by the State of Georgia against the Tennessee Copper and the Ducktown Sulphur, Copper and Iron Company, Ltd. See Georgia v. Tenn. Copper Co., 237 U.S. 474 (1915). Notably, both companies were located in the State of Tennessee.

${ }^{87}$ See Shinya Murase (Special Rapporteur of the Int'l L. Comm'n), Third Rep. on the Protection of the Atmosphere, at 718, U.N. Doc. A/CN.4/692 (Feb. 25, 2016).

${ }^{88}$ In the Gabčikovo-Nagymaros Project case, the Court stated that it "is mindful that, in the field of environmental protection, vigilance and prevention are required on account of the often irreversible character of damage to the environment." Gabčikovo-Nagymaros Project (Hung. v. Slovk.), Judgment, 1997 I.C.J. 7, 140 (Sept. 25).

${ }^{89}$ Liability ex delicto refers to state responsibility for transboundary harm if it failed to take reasonable measures to prevent the harm; liability sine delicto stricto sensu presupposes compensation for transboundary harm even in the absence of fault or negligence; liability sine delicto lato sensu permits transboundary harm as long as it is reasonable and equitable. See Jaye Ellis, Liability for International Environmental Harm, OXFORD BIBLIOGs (2018), https://www.oxfordbibliographies.com/view/ document/obo-9780199796953/obo-9780199796953-0017.xml.

${ }^{90}$ Peter H. Sand, The Discourse on "Protection of the Atmosphere" in the International Law Commission, 26 REV. EUR. COMPAR. \& INT'L ENV'T L. 201 (2017).

${ }^{91}$ See Yulia Yamineva, Is Law Failing to Address Air Pollution? Reflections on International and EU Developments, 26 REV. EUR. COMPAR. \& INT'L ENV'T L. 189-200 (2017).
} 
The situation seems to be rather gloomy on the regional level too, where, although the right is more represented, it remains largely non-justiciable. The San Salvador Protocol to the American Convention on Human Rights, for instance, reads that "everyone shall have the right to live in a healthy environment," but it does not include the right in the short list of economic, social, and cultural rights whose breach may be the subject of a claim to the Inter-American Commission on Human Rights. ${ }^{92}$ Both the Arab Charter on Human Rights and the ASEAN Human Rights Declaration include the right to a "healthy" (Arab Charter) or "safe, clean and sustainable" (ASEAN Declaration) environment as an element of the right to an adequate standard of living, but neither instrument creates oversight mechanisms that can receive complaints in case of a violation of the right. ${ }^{93}$ The right is also not guaranteed by the European Convention on Human Rights and any protocol thereto-which makes the European Court of Human Rights incompetent in that regard. The Court has, in fact, referred to clean air in its judgments, but the violation concerned Article 2 (right to life) and Article 8 (right to private and family life) of the Convention, as previously mentioned. ${ }^{94}$ Likewise, the EU primary law does not expressis verbis mention the right to clean air, albeit such right is inferred from secondary law, in particular from the obligation of Member States to assure adequate air quality, specified in the Air Quality Directive. The European Court of Justice in the landmark Janecek case declared that:

$[\mathrm{N}]$ atural or legal persons directly concerned by a risk that the limit values or alert thresholds may be exceeded must be in a position to require the competent authorities to draw up an action plan where such a risk exists, if necessary by bringing an action before the competent courts. ${ }^{95}$

The Janecek judgment was later confirmed in ClientEarth2, where the Court upheld the right of standing of individuals and NGOs before a national court in order to enforce the Air Quality Directive. Claimants also have the right to a legal remedy, in other words, the right to require the adoption of a plan, and have the right to demand judicial scrutiny of that plan. ${ }^{96}$ Very recently, the Court of Justice of the European Union ruled that the Air Quality Directive demands air pollution limits (in Brussels) to be assessed at monitoring stations where people's exposure to pollution is the greatest, not with an average across an area, thereby setting a good precedent for the rest of Europe. ${ }^{97}$

The EU Member States are also controlled by the European Commission, which can refer a State to the European Court of Justice (ECJ) and impose very high financial fines. For instance, in 2018, the ECJ ruled that between 2007 and 2015, Poland had regularly exceeded the daily limit values for $\mathrm{PM}_{10}$ concentrations in thirty-five out of forty-six zones, whereas the annual limit values for such concentrations were exceeded in nine zones. ${ }^{98}$ In March 2019, the EU Commission decided to take Italy to the ECJ for failure to obey the $\mathrm{NO}_{2}$ limit values in the ambient air prescribed in Directive 2008/50/EC. ${ }^{99}$

\footnotetext{
${ }^{92}$ Additional Protocol to the American Convention on Human Rights in the Area of Economic, Social and Cultural Rights "Protocol of San Salvador" arts. 11(1), 19(6), Nov. 17, 1988, 28 I.L.M. 156; see also Varun K. Aery, The Human Right to Clean Air: A Case Study of the InterAmerican System, 6 SEATTLE J. ENV'T L. 15-38 (2016).

${ }^{93}$ Arab Charter on Human Rights art. 38, May 22, 2004, 12 I.H.R.R. 893; Association of Southeast Asian Nations (ASEAN) Human Rights Declaration art. 28(f), Nov. 19, 2012, https://asean.org/asean-human-rights-declaration/.

${ }^{94}$ In Lopez Ostra v. Spain, the Court held that a waste-treatment plant emitting polluting fumes caused nuisance and Spanish authorities failed to respect the right to private and family life. See generally Lopez Ostra v. Spain, 1994 Eur. Ct. H.R. 46, http://hudoc.echr.coe.int/fre?i=001-57905.

${ }^{95}$ Case C-237/07, Janecek v. Freistaat Bayern, 2008 E.C.R. I-6221, para. 39.

${ }^{96}$ Case C-404/13, ClientEarth v. The Sec'y of State for the Env't, Food \& Rural Affairs, ECLI:EU:C:2014:2382 (Nov. 19, 2014).

${ }^{97}$ See Case C-723/17, Lies Craeynest v. Brussels Hoofdstedelijk Gewest, ECLI:EU:C:2019:533 (June 26, 2019).

${ }^{98}$ See Case C-336/16, European Comm'n v. The Republic of Poland, ECLI:EU:C:2018:94 (Feb. 22, 2018).

${ }^{99}$ European Commission Press Release IP/19/1475, Commission Takes Italy to Court Over Air Pollution and Failure to Properly Treat Urban Waste Water (Mar. 7, 2019). In total, there are fourteen infringement cases pending against
} 
At the national level, the right to clean air is present in the legal acts of the vast majority of countries - mainly as the right to a healthy environment - but regrettably, it remains largely unactionable in and of itself. That being said, the violation of the right is mainly established in conjunction with other human rights. For instance, the district court in Warsaw in December 2018 ruled that smog restricted personal rights of a famous Polish actress, in particular, the freedom of movement and the right to privacy, and ordered the State Treasury to pay 5000 PLN in compensation. ${ }^{100}$ Earlier, citizens and NGOs sought a writ of mandamus in Nepal's Supreme Court against a marble factory which emitted smoke, dust, sands, and minerals, polluting air, land, and water-risking both the life and property of the local population. The court, in its ruling, relied on Nepal's constitutional provisions guaranteeing the right to life-noting, however, that it in large measure depends on healthy air. ${ }^{101}$

Lastly, it is worth emphasizing that many of the environmental rights, including the right to breathe clean air, face adjudication challenges. Vindication of the right to clean air is particularly exacerbated by matters relating to the need for technical expertise, the quantum of evidence needed, and costs to be borne by a state. Hurdles of litigation also relate to the balance between other human rights, such as the right to work and social security. ${ }^{102}$

All things considered, the "piecemeal" enforceability substantially undermines the normative character of the right to breathe clean air. Although some authors claim that enforceability is not a decisive criterion in establishing and acknowledging the existence of a human right and that human rights supervisory bodies assessing states' compliance with their human rights obligations are enough to satisfy the "enforceability requirement," ${ }^{103}$ it is more plausible to side with Handl, who asserts that, at this stage, we cannot talk about the new generic human right to clean air. ${ }^{104}$

\section{Conclusion}

The right to breathe clean air, despite its paramount significance in combatting air pollution, belongs to one of the most perplexing environmental rights. With the lack of autonomy, essentially undetermined content, practical non-justiciability, and the absence at the international level, it is difficult to ascribe legal normativity in the classical sense to the right to breathe clean air. Naturally, there are strong political and economic reasons that obstruct successful vindication of the right before courts and its articulation at the international level. Nonetheless, the situation seems to be gradually changing and there is a glimmer of hope that the right to breathe clean air could turn into a proper legal right. If precedential cases, like those recent ones of the ECJ on the specific measurement of air pollution in Brussels and the Warsaw district court on the detrimental effects of smog on personal liberties will proliferate and develop, they will strengthen the congruity of the right, leading perhaps to direct enforceability of the right in the future. In addition, if states decide to enact separate legal provisions on the right to clean air, like the State of Pennsylvania before and, most recently, the State of New York, then this would definitely exert a positive impact

\footnotetext{
Member States for exceeding NO2 limits: Austria, Belgium, the Czech Republic, Germany, Greece, Denmark, France, Spain, Hungary, Italy, Luxembourg, Poland, Portugal, and the United Kingdom. See id.

${ }^{100}$ Wyrok [judgment] Sąd Rejonowy dla Warszawy-Śródmieścia [District Court in Warsaw] Jan. 24, 2019, VI C 1043/18 (Pol.). Subsequent cases brought by publicites Mariusz Szczygiel, Jerzy Stuhr, and Tomasz Sadlik have also been successful.

${ }^{101}$ Suray Prasad Sharma Dhungel, WP 35/1992; see also David R. Boyd, The Implicit Constitutional Right to Live in a Healthy Environment, 20 Rev. Eur. Compar. \& InT'L ENV'T L. 171-79 (2011); Adriana F. Aguilar, Enforcing the Right to a Healthy Environment in Latin America, 3 Rev. Eur. COMPAR. \& INT'L ENV'T L. 215-22 (1994).

${ }^{102}$ See Clean Air Found. Ltd. v. The Gov't of the Hong Kong Special Admin. Region, 2007 H.K.C. 757 (China).

${ }^{103}$ Antonio Cançado Trindade, The Contribution of International Rights Law to Environmental Protection, with Special Reference to Global Change, in ENVIRONMENTAL CHANge AND INTERnAtional LAw: New CHALlENGES AND Dimensions 302-04 (Edith Brown Weiss ed., 1992); Luis E. Rodriguez-Rivera, The Human Right to Environment in the 21st Century: A Case for its Recognition and Comments on the Systemic Barrier it Encounters, 34 AM. U. INT'L L. REV. 148 (2018).

${ }^{104}$ Handl, supra note 75 .
} 
on the apprehension and clarity of the right, which, in turn, would translate to greater adherence. Finally, there is hope that the UN General Assembly will follow its praiseworthy attitude towards the right to safe drinking water and sanitation in 2010 and recognize the right to clean air-perhaps determining its content-which will attribute a greater significance and prestige to the right as well as enable methods for claiming it before international bodies. Without these progressive steps, it will remain troublesome to talk about the right to breathe clean air. 